\title{
Ogólnopolska konferencja naukowa pt. Kwestie majątkowe $w$ prawie wyznaniowym, Dwikozy k/Sandomierza, 15-16 września 2016 r.
}

W dniach 15-16 września 2016 r., w Dwikozach k/Sandomierza (w urokliwym hotelu „Dwór Dwikozy”) odbyła się ogólnopolska konferencja naukowa zatytułowana Kwestie majątkowe w prawie wyznaniowym, zorganizowana przez Polskie Towarzystwo Prawa Wyznaniowego i Katedrę Prawa Publicznego Wydziału Zamiejscowego Prawa i Nauk o Społeczeństwie KUL w Stalowej Woli. Wzięli w niej udział przedstawiciele licznych ośrodków akademickich w kraju, łączący w wielu przypadkach pracę naukową z praktyką zawodową, uczestnicy mogli zatem konfrontować teorię z praktyką, co niewątpliwie podniosło walor poznawczy spotkania. Dobrą tradycją konferencji prezentujących problematykę prawa wyznaniowego stała się obecność na nich przedstawicieli ministra właściwego do spraw wyznań religijnych. Tym razem przybyło dwoje doświadczonych pracowników z Departamentu Wyznań Religijnych oraz Mniejszości Narodowych i Etnicznych Ministerstwa Spraw Wewnętrznych i Administracji, w osobach mgr Moniki Piszcz-Czapli Naczelnika Wydziału Regulacji Prawnych w DWRMNiE oraz mgr. Mariusza Radajewskiego - Naczelnika Wydziału Rejestru kościołów i innych związków wyznaniowych w DWRMNiE.

Po powitaniu gości przez dr. hab. Marka Bieleckiego (KUL), głos zabrał dr hab. Leszek Ćwikła - Dyrektor Instytutu Prawa i Ekonomii WZPiNoS KUL w Stalowej woli. Powitał wszystkich uczestników w imieniu własnym i Dziekana WZPiNoS - prof. dr. hab. Andrzeja Kuczumowa, wyrażając radość z tak licznego przybycia zaproszonych gości i podkreślając aktualność wybranego przez organizatorów tematu. Następnie Prezes PTPW - prof. UO dr hab. Paweł Sobczyk, witając prelegentów, wyraził swoją wdzięczność za pracę włożoną w przygotowanie referatów.

Moderatorem pierwszej sesji zatytułowanej Sprawy finansowe jako element działalności kościołów i innych związów wyznaniowych był prof. zw. dr hab. Artur Mezglewski (UO). Jako pierwszy zabrał głos dr Michał Skwarzyński (KUL), który wystąpił z referatem pt. Źródta ochrony praw majątkowych związków wyznaniowych w systemie praw człowieka, podkreślając ścisłą korelację pomiędzy majątkiem jakim dysponują kościoły i związki wyznaniowe, a koniecznością przestrzegania praw człowieka. Jako drugi w tej sesji wystąpił dr Michał Zawiślak (KUL) z przedłoże- 
niem pt. Uprawnienia majątkowe i obciązenia fiskalne Kościoła katolickiego. Obok gwarancji do posiadania i dysponowania majątkiem, autor przeanalizował katalog obowiązków w zakresie podatków nakładanych na kościelne osoby prawne. Nieco pesymistyczny wydźwięk miało wystąpienie prof. UO dr hab. Pawła Sobczyka pt. Czy potrzebna jest nowa polityka prawa wyznaniowego $w$ zakresie spraw finansowych? Prelegent zauważył bowiem, że w Polsce od szeregu lat nie prowadzi się nowej polityki prawa wyznaniowego, która odkładana jest przez prominentne władze na dalszy plan. Dlatego też sformułował postulat zmiany owego nastawienia, z uwagi na konieczność rozwiązania wielu kwestii wymagających natychmiastowego reagowania. Ostatnie w tej sesji wystąpienie zatytułowane Utrzymanie duchownych $w$ przepisach państw europejskich. Studium porównawcze, zaprezentował dr Maciej Kubala reprezentujący Sąd Kościelny Diecezji Zielonogórsko-Gorzowskiej. Autor podjął się bardzo trudnego zadania, polegającego na prezentacji w syntetyczny sposób modelów rozwiązań występujących w całej Europie. Po zakończeniu wystąpienia odbyła się ciekawa dyskusja, podczas której pytania kierowane były do wszystkich autorów.

Druga sesja pt. Kwestie majątkowe zwiazane z działalnościa kościotów i innych związów wyznaniowych została podzielona na dwie części. W pierwszej przewodniczył prof. UO dr hab. Paweł Sobczyk. Pierwszy referat pt. Proboszcz jako zarzadca zabytków sakralnych został wygłoszony przez mgr lic. Marka Paszkowskiego z parafii pw. św. Anny w Barczewie. Uczestnicy mieli okazję zapoznać się z praktycznymi problemami, z jakimi musi radzić sobie proboszcz, na którym spoczywają liczne obowiązki z tytułu opieki nad zabytkami. Zagadnień polityki PRL-u w stosunku do kościołów i związków wyznaniowych dotyczyło wystąpienie prof. UO dra hab. Andrzeja Szymańskiego pt. Likwidacja przez władze wyznaniowe Bractwa św. Anny w Piotrkowie Trybunalskim oraz ograniczenie możliwości funkcjonowania Bractwa Literaków w Warcie w latach 1959-1960. Następny prelegent, którym był dr Michał Chajda (WSFiP w BielskuBiałej), zajął się zagadnieniem skuteczności norm wewnętrznych kościolów i związków wyznaniowych w systemie prawa polskiego, od wielu lat obecnym w literaturze przedmiotu. Dokonał tego analizując zagadnienie zaciągania zobowiązań przez kościelne osoby prawne. $Z$ ostatnim referatem w pierwszej części sesji pt. Zarządzanie cmentarzami wyznaniowymiaspekty finansowo-prawne, wystąpił dr Mateusz Pszczyński (UO). Podjął się on charakterystyki kontrowersyjnej tematyki pobierania opłat przez 
kościelnych zarządców cmentarzy z tytułu chowania zmarłych. Autor wskazał m.in. na liczne rozbieżności w stosowanych praktykach.

Przewodniczenie drugiej części sesji objął prof. UO dr hab. Dariusz Walencik, który jako pierwszemu oddał głos dr. Michałowi Poniatowskiemu (UKSW), prezentującemu referat pt. Prawo spadkowe $w$ działalności kościelnych organizacji charytatywnych. Prelegent zajął się problematyką legitymacji prawnej kościelnych osób prawnych zajmujących się działalnością charytatywną $\mathrm{w}$ zakresie spadkobrania. Tematyce roszczeń rewindykacyjnych osób prawnych Kościoła katolickiego obrządku bizantyjsko-ukraińskiego po likwidacji Komisji Majątkowej, poświęcił swoje wystąpienie dr hab. Marek Bielecki (KUL). Autor przeanalizował główne problemy, z którymi stykają się kościelne osoby prawne w toczących się od pięciu lat postępowaniach sądowych. Zagadnień finansowych w prawie kanonicznym dotyczyło wystąpienie dr Justyny Krzywkowskiej, która wygłosiła referat pt. Koszty sądowe $w$ procesie o nieważność matzeństwa. Perspektywa polska. Uczestnicy konferencji mogli dowiedzieć się o niejednolitych praktykach występujących w polskich sądach kościelnych. Po zakończeniu drugiej części sesji odbyła się dyskusja.

Podobnie jak poprzednia, również trzecia sesja pt. Polityka finansowa państwa wobec kościołów $i$ innych związków wyznaniowych została podzielona na dwie części. Wynikało to, jak podkreślił jej moderator prof. zw. dr hab. Tadeusz Jacek Zieliński (ChAT), z bogactwa zgłoszonych referatów, które mieściły się ww. tematyce. $Z$ pierwszym przedłożeniem zatytułowanym Zasady finansowania Caritas Archidiecezji Przemyskiej, wystąpił dr Leszek Krzyżak (PTPW). Jako kolejny zabrał głos prof. UO dr hab. Dariusz Walencik, prezentując zagadnienie dotyczące zasad funkcjonowania funduszu kościelnego w latach 2010-2016. Ostatni w pierwszym dniu konferencji referat pt. Polityka majatkowa władz PRL wobec diecezji łódzkiej w świetle kwestionariusza położenia Kościoła $w$ Polsce $w$ latach 1945-1964, zaprezentował prof. UWM dr hab. Mieczysław Różański.

Drugi dzień konferencji rozpoczął się od wznowienia trzeciej sesji, z moderacją prof. UR dr. hab. Piotra Steczkowskiego. W pierwszej kolejności wystąpił mgr Michał Ożóg (UJ), prezentując temat finansowania duszpasterstwa specjalnego w podmiotach leczniczych. Jako następny głos zabrał prof. zw. dr hab. Artur Mezglewski (UO) z referatem dotyczącym finansowania nauczania religii ze środków publicznych w świetle zasady bezstronności. Z kolei mgr Rafał Kaczmarczyk przybliżył uczestnikom tematykę opodatkowania i zwolnienia z podatku od nieruchomości Muzuł- 
mańskiego Związku Religijnego w Rzeczypospolitej Polskiej. Trzecia sesja została zakończona referatem prof. zw. dr. hab. Bartosza Rakoczego (UMK) pt. Cywilno-prawne skutki zrzeczenia się dóbr wedtug kan. 668 Kodeksu Prawa Kanonicznego. Po zakończanym wystąpieniu odbyła się dyskusja podsumowująca z licznymi pytaniami ze strony uczestników konferencji.

Czwarta, a zarazem ostatnia sesja konferencji, została zatytułowana Perspektywa międzynarodowa. Jej moderatorem został prof. zw. dr hab. Bartosz Rakoczy. Pierwsze wystąpienie prof. UKSW dr. hab. Piotra Ryguły, poruszało zagadnienia finansowania Kościoła katolickiego w Hiszpanii. Aspekty majątku organizacji religijnych na Ukrainie zostały zaprezentowane w referacie dr. Jerzego Nikołajewa (WSSMiKS). Prof. UR dr hab. Piotr Steczkowski omówił regulacje prawne dotyczące majątku kościołów i innych związków wyznaniowych w Federacji Rosyjskiej. W referacie prof. zw. dr. hab. Tadeusza Jacka Zielińskiego zaprezentowana została tematyka zagadnień prawnych majątku niepaństwowych wspólnot religijnych w Anglii. Z kolei mgr Jakub Cupriak (ChAT) podjął się omówienia zagadnienia dotyczącego majątku związków wyznaniowych w Niemczech. Ostatnią prelegentką sesji, a zarazem całej konferencji była dr Marta Osuchowska (UKSW). Jej referat poświęcony był systemowi finansowania Kościoła katolickiego w Argentynie.

Po bardzo interesującej dyskusji, dr hab. Marek Bielecki podziękował w imieniu organizatorów wszystkim uczestnikom i wyraził nadzieję, że nieporuszone wątki, zostaną szerzej ujęte w monografii pokonferencyjnej. Należy zauważyć, co wielokrotnie podkreślano w dyskusjach kuluarowych, że wygłoszone referaty zostały bardzo dobrze przygotowane pod względem merytorycznym i wypada mieć uzasadnioną nadzieję, że wspomniana publikacja będzie stanowić doskonały materiał poznawczy dla zainteresowanych tą, niewątpliwie ciągle aktualną, problematyką.

Dr hab. Marek Bielecki Wydział Zamiejscowy Prawa i Nauk o Społeczeństwie w Stalowej Woli Katolicki Uniwersytet Lubelski Jana Pawła II 